\title{
A CASE OF HYPERNEPHROMA WITH METASTASIS TO THE RIGHT ETHMOIDAL SINUS
}

$\mathrm{By}$

J. KAWAI, M. ICHIKAWA AND N. MISHIMA

From the Department of Oto-Rhno-Laryngology, Yokohama University School of Medicine (Director: Prof. T. Kashiwado) i...

A 66 years old female visited our hospital complaining severe nasal bleeding.

She had right nephrectomy for a renal tumor 4 years ago, and had been suffering from the nasal obstruction, purulant nasal discharge and migrene on the right side for about 4 months. She had been having nasal bleeding for one week.

Rhinoscopic examination revealed a polypoid mass between the nasal septum and right middle turbinate.

On the $\mathrm{X}$-ray film, a thumb-tip-sized shadow was seen in the nasal cavity and the median wall of the ethmoidal sinus was compressed towards the nasal cavity.

The tumor was removed, and histological examination revealed hypernephroma.

The postoperative course was uneventful.

\section{穊骨蜂笨に認められた Hypernephrom の 1 例}

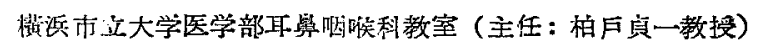 \\ 助手

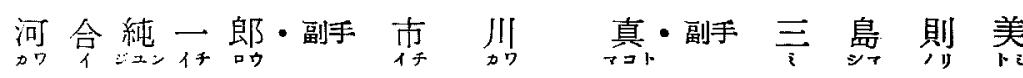

主訴：右鼻出血.

\section{緒言}

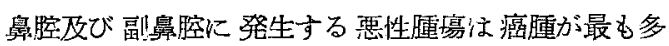
く，その他肉腫，内被細胞腫等が挙げられている・し かるに Hypernephrom に就いては, 本腫境が鼻腔, 副鼻胵に見られた報告は極めて少く、我くの識り得た範

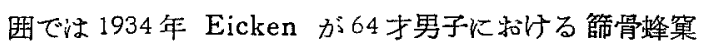
の Hypernephrom を報告したのが最初で，次いで 1936 年 Carnevale Ricci は前頭洞炕打る本腫瘍の 1 例を 報じ, 更に1938 年には Chales E. Cornor は52才女 子前頭洞，篩骨蜂煲及び上顎洞に見られた転移性の本腫 癔を報告し，最近では 1955 年62 才男子鼻中隔に見られ た1例が Achar によつて報告され，又本邦て乱いては 僅かに 1939 年黒川により左上顎洞に発生した本腫福の 1 例が発表されているのみである。而して我々は最近篩 骨蜂笨に 発生した本腫倣の 1 例を経験したので報告す る.

$$
\text { 症例 }
$$

㭧者：66 才女子.

初診：昭和 31 年 7 月 11 日.

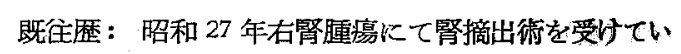
る。

家族歴：特記するものなし.

現病歴：昭和 31 年 3 月中旬頃上り右鼻閉及び膿性鼻 漏を自覚，且つ次第に堌強し，又その頃上り右前頭部よ り側頭部にかけ頑固な疼痛をきたしたが鎮静㓣を服用， 奶置していたところ，初診前 1 週間頃より鼻漏に血液を 混じ， 7 月 10日夜右鼻腟より多量の出血をきたした〉め 同夜は内科医より応急奶置を受け，な打完全沚血せぬ ため翌日来院した。

局所々見：右鼻腔は凝血充満し，これを除くと可店 りの出血を見たがその際の鼻腔所見は第 1 図の如く右中 甲介は浮腫脹以高度に腫脹し，㖵裂部より暗赤色出血性 の鼻茸様組織が鼻胵内に膨出しており，この部は綿柾の 先端が触れてす出血をきたした。後鼻鏡検查仙㠜血のた ぬ不明であつた，又右鼻根部に 軽度の 腫脹と 区痛を露

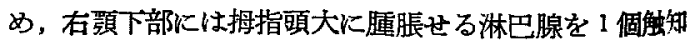
した・左鼻腔には異常を認めず. 


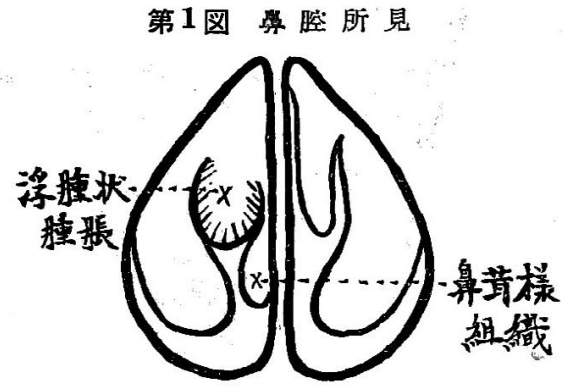

第 2 図

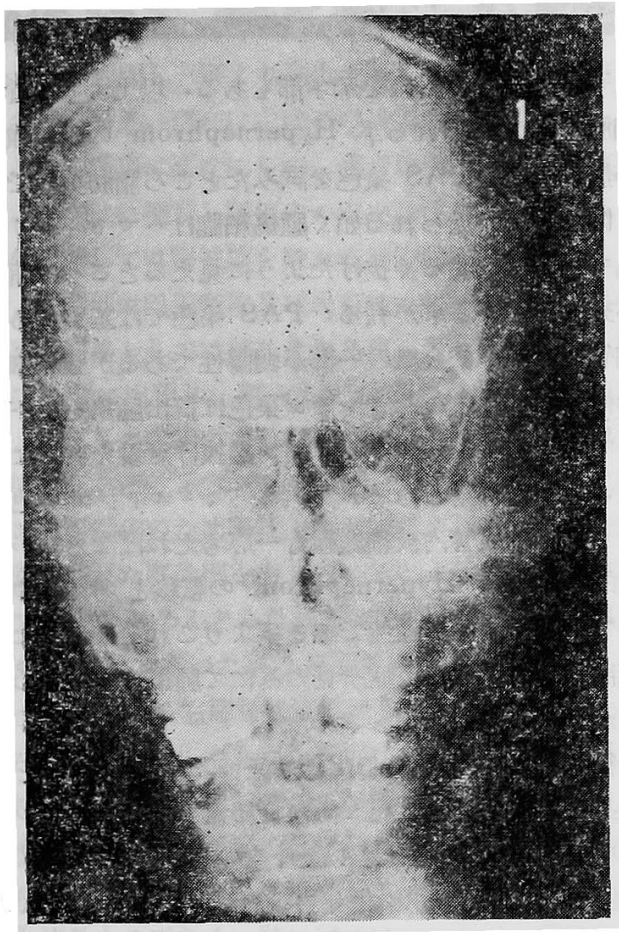

耳, 咽诶頭正常.

鼻部レントゲン 所見：第 2 図の如く右篩骨峰笨部に 拇指頭大の陰影を呈し，且つこの部の右鼻胵側壁は中心 部に向い圧迫され骨破壊像が認められる。

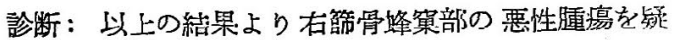
い, 右鼻腔鼻茸椂組織を 1 部印除乙病理組織学的検查を 行つたところ，血管内被細胞腫の疑を有した・

よつて手術をすつめたが患者がこれを承諾せぬため諸

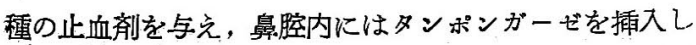
経過を観察していた。しかしながらその後も鼻出血継続 し且つ増強の傾向を示したので8月 8 日入院した。

一般状態：入院時顔貌は高度の盆血状を呈し，全身
瘦赢，栄養状態不良なるも脈搏正常，瞳孔反射，腱反射 異常なく，胸部は聴打診にて異常を認めず，四腅その他 に浮腫も認められぬ・腹部は右季协下部に表面平滑な硬 い手拳大の腫瘤を解知し軽度の圧痛を有した。㕛腹背部 右側の支膚には简摘出術火上る䑤痕が認められた。

血圧は最高 $135 \mathrm{mmHg}$, 最低 $80 \mathrm{mmHg}$.

眼球突出を認めず。眼球運動, 眼底所見も正常.

㽷所見：反応は弱酸性，蛋白及びウロビリノーゲン 中等度陽性なるも沈渻には特異なるのを認めなかつた。

血液所見：

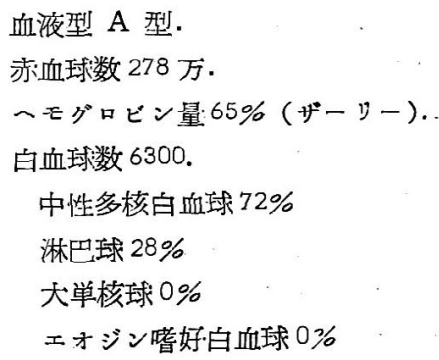

入院後 8 月9 日早朝再び右鼻腔より多量の出血をきた したつわ患者も遂に手術を承諾し8月11日手術を施行 した。

手術所見：先ず拇指頭大に腫脹せる 右顎下淋巴腺を

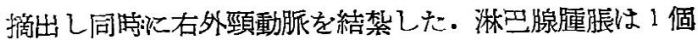
のみで且つ周囲との癒着は軽度であつた，次いで右咸面 にWeber 氏法により皮膚切開を行い上䫟洞を開放し た. 洞内には覀具ある乾酪様物質充満し洞粘膜肥厚高度

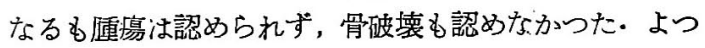
て皮署切開を上方眉毛の内側端迄延長し, 斾骨蜂窂の顔 面壁を充分蕗出した。而して骨壁に啭壊像を認めず。

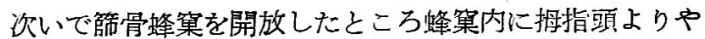

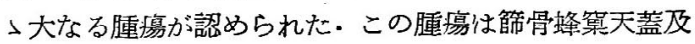
び自然孔部の骨と癒着し 自然孔部の骨を鼻腔側兄氏迫 し，且 1 部を破壊し固有鼻腔内に膨出して执つたが，篩 骨蜂巢内の他部比いては瘾着及び骨破壊, 周囲えの浸 潤は認められず腫掦はその周囲を恰も被膜にて覆われて いるかの如き外観を呈した・自然孔部においては周囲と の慮着強きためこの部の骨及び中甲介は腫昜と共に摘出

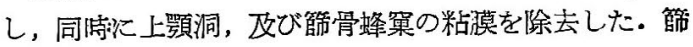
骨蜂笨粘朕は高度に肥厚し旦大部分は壊死状を呈して いた. 腆瘍摘出に際しては多量の出血を見たが壬迫タン ポンを創内に挿入し，1次的に皮度縫合を行い，強き区 
迫繃帯を行つて術を終つた・な报街中リ、ンゲル氏夜 1000 cc と血液 $400 \mathrm{cc}$ の点㖕静注を行つた.

摘出通煌の肉眼的所見：犬ささは拇指頭大よりや〉 大で表面平滑，弾力性を有し1部浮腫状，1 部梳㱜状 を呈するも大部分は暗赤色で肉塊状を呈した．割面け腫 㾕の鼻腔側壁えの癒着部を中心としこれょり周辺に向い 星芒状洕道椂を呈し，その他の部は暗黄赤色にてところ どころに出血点が認められた。

病理組織学的所見：摘出腫㾤の病理組織学的所見は へマトキシリンーエオジン染色では第3 図の如くであり， これを更に強拡大にすると第 4 図に示す如く, 腫瘍細胞 は形恃不定なるも一般に立方形で多量の原形質を有し， 極めて明るく原形質物質は殆んど 無いかの如く見られ る・併し細胞間境界はエオジン中等度赤染し, 比較的明 瞭である・核は大きさは淋巴球よりや小ささで形は円 形状，クロマチン量中等度，核小体は一般に見難い、斯 かる細胞群は大部分は毛細管を，一部は第 3 図に和いて 見られる如く線維結:合織を基貿として発育しており大小 稙々の肺胞様の排列を示す. 又第 4 図纪示す如く基質た る毛細筞はその内腔が狭少なるものもあるが，所によつ

\section{第 3 図}

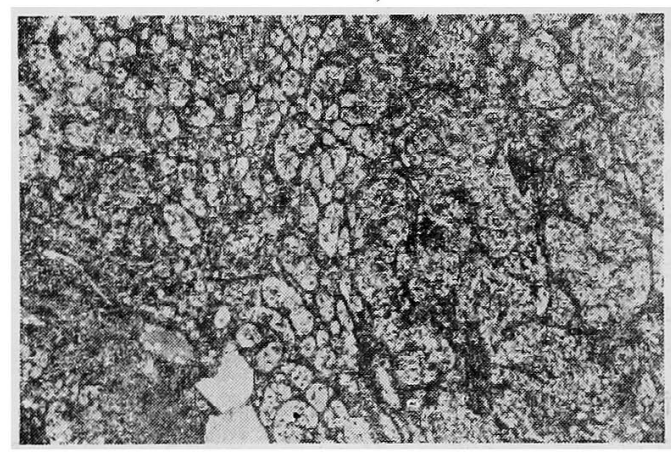

第 4 図

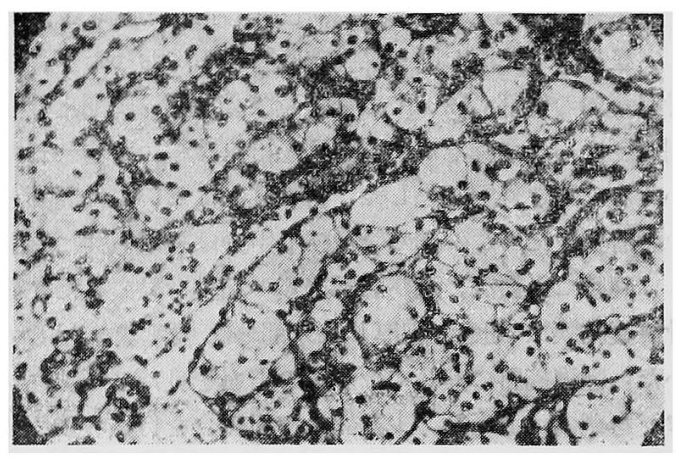

第 5 図

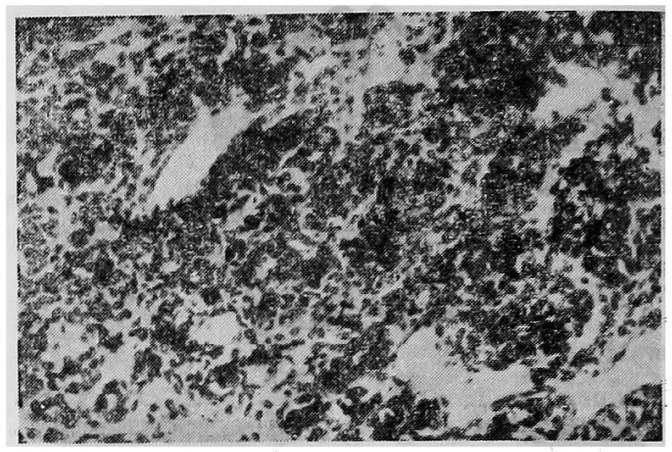

ては著しく拡張し出血を示す部もある. 以上より血管内 被細胞腫も考穴られるが Hypernephrom の簃が強い. ため脂肪染色, PAS 染色を試みたところ脂肪染色では 第 5 図に招いて見られる如く腫瑔細胞はへマトキシリン 染色で見られた明るく拔けたように見觉るところに脂肪 球が充満している事が判る.PAS 染色では基質である

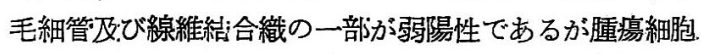
は陰性であつた.な㧍っルミン染色は摘出腫瘍をホルマ リンで固定した〉めグリコーゲンが拔け意義を有しなか. つた. 以上の所見からへマトキシリンーエオジン染色の みよりすると血管内被細胞腫も一応考光ねばなら奴， 全般的な像では Hypernephrom の転移と考えるのが 妥当で，脂肪染色が陽性である事よりこれを碎信した.

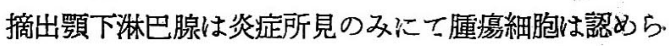
れなかつた。

術後経過：術後 1 日目には血圧 $90 \mathrm{mmHg}$ 以下とな り全身哀弱の兆を示したつめ毎日輸血 $100 \mathrm{cc}$, ペニシリ ン 60 万単位, パラキシン $10 \mathrm{gr}$, 強心成, リンゲル1000 cc 注射を継続したが術後 3 日目に肺炎を併発したつめ. 更に酸素吸入、ストレプ、イシン注射を行つた・しか. るところ 5 日目より解熱し全身状態も恢復したのでべ= シリン及びパラキシン以外の注射は中止し, 叉術創のガ 一ゼタンポン交换は 5 日目より開始し 11 日目には全部 除去し終つたが出血は殆んど誑めなかつた。文顔面の手

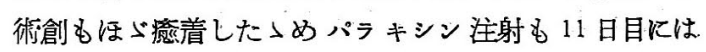
中止した．以後は術創の渄临を継続していたが出血なく 清浄となつたので術後 21 日目にはン゚ニシリン注射も中. 止し28日目には元気で退院した。以来現在に至る迄全 く異常を認めず，尿所見にも著変なく，右季肋下部の腫 瘤もまた術前と同㴍の状態である。

\section{総括並びに考按}

Hypernephrom とは1883 年 Grawitz が靔にれい 
て発見した 副督皮質に 類似する構造を有する 腫湯で， 1896 年 Birch-Hirschfeld 等により Hypernephrom と命名されたものである. 本腫悬は腎腫瘍の 60 乃至 70 \%を占め多くは癌の形態をとるるのである. 組織学的に は脂肪及びグリューゲンに富み，多量の原形質を有する 大きな腫穿細胞が血管と密に運絡しながら配列し，この 細胞が副腎皮翼細胞に極めて類似している．而してその

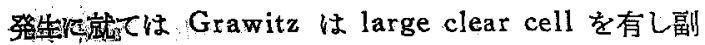
腎皮䀇組織心似た構造を有する点より副腎の迷䓔より発 生すると晿えた。しかるにその後 1893 年 Sudeck 及び 1908 年 Stoerk は㻉の細尿管上皮より発生する Adenoma に起因し，腎より発生するすので副腎とは無関俰 てあると唱え，現在は主にこの後者の説が支持せられて

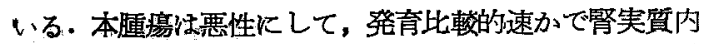
では浸潤性に発育し腫逼内の出血及び壊死を起し易く， 腎外に対しては腎被膜を破り直接脂肪埕に波及すると共 に，筲門部淋巴腺転移及び血行性の転移をきたし易い。 血行性転移としては肺にきたる事が最も多く，次いで肝 並びに骨に出現し，時としては原発巣は潜在性に経過

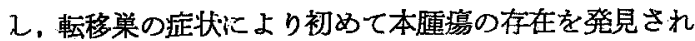
る場合もある.我々の症例に沶いては昭和 27 年に某病 院で右腎腫昜のため緊摘出術を施行されその際癌である と診断された既往歴を有している・よつてその腎尰敫に 就て䛨細を碓めんとしたが明確な記載無さため Hypernephrom であつた事は確琴し得なかつた，併しその

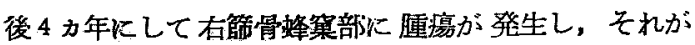
Hypernephrom であつた事実は，先の腎腄湯は恐らく Hypernephrom にしてこれが篩骨蜂窠に転移をきたし たるの上考えるのが妥当と思われる．又同蛅に右李牞下 部に触知される腫缷る転移栄が本部泣に存在する事を想 わしめるすのである.胡に就てはレントゲン像においいて 目下のところ転移と考えられる所見は認められていな w.
結 語

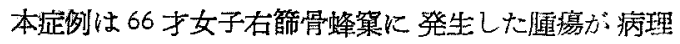
組織学的検查により Hypernephrom と誩断せられ， 摘出維により良好な経過を示した例で，本例の如く，鼻 腔, 副鼻舩に Hypernephrom が認められた坏告は我 トの調查し得た範囲では 5 例を算えるのみで，その内容 は前頭洞 1 例，篩骨䗋僧 1 例，上顎洞 1 例，前頭洞上り

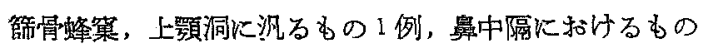
1 例である.よつて右節骨蜂集に見られた我トの症例当 稀有なものとして報告する次第である.

\section{参文 献}

1) Eicken, C.V.: Zeitschrift f. Laryngolog. L.s.w . 25, (1934). $\quad$ 2) Carnevale Ricci, F.: Arch. ital. Otolog., 4, s. 48, (1936). 3) Cornor Charls E..: Arch. of Otolaryngology. 28, (1938). 4) M.V. R. Achar: A.M.A. Archives of Otolaryngology . Vol. 62, No. 6, (1955). 5) 黑川慗一：大日本다. 算腘喉科会々報, 46 卷, 9 号, (炤利 15 年). 6) 日 本耳鼻咽䐅科全菁，第 2 卷，第 4 册，(梠和 30 年).

7) Peter A. Herbut: Urological Pathology. (1952). 8) 楠隆光：小泌尿器科学，(炤和 30 年). 9) 志賀 管, 窝川梁次他 2 名: 泌尿器科学, 下卷, (炤和 27 年). 10) Meredith Campbell, M.S., M.D.: Urology Vol. 2. (1954).

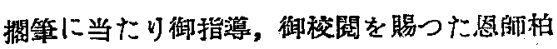

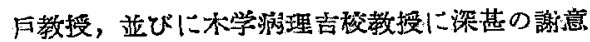
を表し，本学泌尿器科㡿本助手の衔期言を感謝 します。

本報告は日耳昱関東地方会第 345 回例会にお いて発表した。

（原稿到着=昭和 33.9.26日） 